\title{
DE RELICÁRIOS A JANELAS: \\ OBJETOS MATERIAIS COMO MENSAGEIROS DA (INVESTIG)AC̣ÃO ESCOLAR
}

\author{
Gisela Marques Pellizzoni* \\ Sonia Regina Miranda**
}

\begin{abstract}
RESUMO: Este artigo pretende discutir a potencialidade pedagógica inerente à produção de objetos de cultura material e o estímulo à sua circulação entre escola e famílias. Baseia-se em experiência de pesquisa que culminou na elaboração de uma dissertação de Mestrado relativa à temática da cultura popular na escola. $\mathrm{O}$ foco particular assumido nesta discussão recai sobre o circuito percorrido por caixas compostas por objetos mnemônicos produzidos e selecionados pelas próprias crianças e em que medida tais objetos foram apropriados e ressignificados pelas famílias.
\end{abstract}

Palavras-chave: Ensino de História; Cultura Popular; Memória; Objetos de Cultura.

FROM RELIQUARIES TO WINDOWS:

MATERIAL OBJECTS AS COURIERS OF SCHOOL INVESTIGATION AND ACTION ABSTRACT: This paper discusses the pedagogical potential of the production of material cultural objects and the promotion of their circulation between the school and the students' families. This is an account of an experimental research carried out as part of a Master's degree in the broad area of popular culture at school. We will focus on the course of a number of boxes containing mnemonic objects produced and selected by the children themselves and the extent to which these objects were accepted and reinterpreted by the families.

Keywords: History Teaching; Popular Culture; Memory; Cultural Objects

\footnotetext{
* Mestre em Educação pela UFJF, professora da Escola Municipal José Calil Ahouagi (Rede pública municipal de Juiz de Fora, MG).E-mail: gisapeliz@hotmail.br

** Doutora em Educação pela Unicamp, professora da área de Teoria de Metodologia do Ensino de História da Faculdade de Educação e do Programa de Pós-Graduação em Educação da UFJF. E-mail: sonia.miranda@ufjf.ed.br
} 
De todos os objetos, os que mais amo são os usados. As vasilhas de cobre com as bordas amassadas, os garfos e as facas cujos cabos de madeira foram tocados por muitas mãos. Estas são as formas que me parecem mais nobres. Estes ladrilhos de velhas casas gastos por terem sido pisados tantas vezes. Estes ladrilhos por onde cresce a grama me parecem objetos felizes. Impregnados do uso de muitos, muito transformados, foram aperfeiçoando suas formas e se fizeram preciosos.

Berthold Brecht

\section{FIOS DE HISTÓRIA E DE MEMÓRIA:}

\section{SOBRE $O$ LEMBRAR, $O$ ESQUECER E O DESCARTAR NO COTIDIANO DA ESCOLA}

A Memória elucidativa das dinâmicas que se processam no interior dos percursos de escolarização tem sido - embora valorizada entre os estudiosos de currículo e da cultura escolar - ainda fortemente sujeita à dialética envolvida no movimento lembrar-esquecer. Quando aludimos a esse movimento dinâmico, porém contraditório, podemos compreender o apagamento dessa memória como algo que vai além do esquecimento involuntário e, por isso, produz sentidos e engendra significados particulares, nos termos daquilo que nos é apresentado pelos historiadores e estudiosos da Memória (LE GOFF, 1994; NORA,1993; RICOEUR, 2007).

Pode-se dizer o mesmo em relação aos produtos e objetos de cultura material que podem transmitir para nós e para os outros, aquilo que se passa no cotidiano da escola. De um modo geral, acostumamo-nos, no dia-a-dia escolar, à normalidade das operações de eliminação dos rastros deixados pelas múltiplas formas de escritas escolares e pelos objetos produzidos por professores e crianças. O que pretendemos neste artigo é refletir sobre uma experiência em que a preservação voluntária de alguns objetos particulares e sua transformação utilitária passou a se projetar como signo e sinal, nos termos evocados por Carlo Ginzburg (1989), e abriu, numa escola singular, um caminho investigativo e pedagógico que acabaria por redimensionar aspectos importantes envolvidos na relação entre aquilo que se passa na sala de aula e a forma como os saberes gerados pelo trabalho escolar atravessam e redimensionam os elos entre escola e família.

A questão central de estudo que esteve na base dessas reflexões (PELIZZONI, 2007) consistia em compreender se uma escola pública, a partir do trabalho com as tradições da cultura popular, poderia se constituir como possivel espaço de revitalização da teia que une e intercambia experiências entre as diferentes geraçoes. Buscou-se, naquela pesquisa de Mestrado, compreender como as crianças e suas famílias ressignificam as práticas de cultura popular traba- 
lhadas na escola a partir de seus próprios referenciais culturais e imaginários, buscando perceber como e se, a partir destas práticas, o elo que une passado e presente pode se revigorar. Neste sentido, cabia responder, em primeiro lugar, se é ou não possível, realmente, a escola vir a se constituir como espaço fecundo para o adensamento das redes de transmissibilidade pautadas na oralidade. Em segundo lugar, cabia compreender se é possível e viável que as tradições e práticas tidas como essencialmente populares sejam trazidas e divulgadas como parte do currículo escolar, em que pese a ocorrência, em muitos casos, da perda de sua sacralidade e sua dimensão simbólica originalmente presentes nas práticas culturais populares (PEREIRA, 2002).

A atenção particular ao micro, aos significados inerentes aos pequenos detalhes verificados na ação cotidiana, o zelo para com a recuperação das evidências e indícios, no sentido atribuído por Thompson (1981), viriam a se constituir no eixo teórico-metodológico central que passaria a nortear não só a pesquisa, mas a própria ação docente cotidiana, que, também, seria a ação organizadora da pesquisa. Desta forma, assumiu-se a posição de pesquisador, durante todo o estudo, como lugar de fronteira, um não-lugar, que Barbier tão bem define como "uma dialética que articula constantemente a implicação e o distanciamento, a afetividade e a racionalidade, o simbólico e o imaginário, a mediação e o desafio, a ciência e a arte". (BARBIER, 2002, p. 18).

Foi a partir deste fazer-refletir-fazer-inventar-reinventar que surgiu o modo como esta pesquisa iria ganhar forma. Era preciso, para que a investigação fosse possível, que o vivido na escola, a partir das tradições, chegasse até as famílias de outra forma, para além dos relatos das crianças. Era preciso se criar uma ponte, um elo que comunicasse a experiência. E foi a partir daí que surgiu nosso instrumento de pesquisa: caixas guardadoras de memórias dos trabalhos realizados na escola.

Seria impossível, nesta publicação específica, dar conta de todos os aspectos verificados naquela pesquisa e nem seria esta nossa intenção. Por esta razão, nosso foco aqui recairá sobre uma dimensão particular da pesquisa: sua opção em termos de caminho metodológico e os resultados auferidos a partir da análise das redes de significados construídos pelas viagens das caixas e seus objetos. 


\section{PRODUZINDO RELICÁRIOS:}

\section{caixas e objetos escolares em ações didáticas e em caminhos investigativos}

A polifonia e a dinâmica curricular que se instaura no interior das salas de aula geram muitas situações de esquecimento derivados do desgaste temporal. Via de regra, tanto os estudantes quanto nós, professores, esquecemos aquilo que pauta a ação cotidiana ao longo do ano na medida em que dias, meses, conteúdos, materiais, provas e unidades temáticas vão se alternando e apagando registros daquilo que se passou. Geram-se, assim, lapsos de lembrança em relação ao que se projeta de modo mais significativo. Neste sentido, partimos do princípio norteador de os artefatos de memória, no interior de situações escolares, dependendo dos significados produzidos em torno de sua produção e fixação, poderem vir a reduzir o efeito corrosivo do tempo sobre a memória, nos termos propostos por Astor Diehl (2002). Sob o ponto de vista de uma educação histórica lato sensu, isso significa criar condições para que a reflexão sobre as práticas de memória se fortaleça como pré-requisito para um processo de formação da consciência histórica (RUSEN, 2001; LUCINI, OLIVEIRA; MIRANDA, 2007).

Os baús ou caixas de guardados utilizados na pesquisa que pauta nossa experiência foram criados com o objetivo de abrigar a memória do vivido com as crianças na escola e, conseqüentemente, prolongar a experiência daí gerada. São caixas simples, produzidas nas frestas e restos de uma sociedade de consumo, oriundos de sucatas e coisas que virariam lixo, encapadas com panos, pinturas e brilhos, nas quais eram guardados os objetos significativos coletados e confeccionados durante o tempo da experiência. No decorrer do longo tempo do trabalho escolar com temas de cultura popular, inspirado na dimensão de experiência inerente à tradição (BENJAMIN, 1987 e AGAMBEN, 2005), foram sendo recolhidos os objetos significativos que deram vida e sentido às experiências vividas: os brinquedos feitos, os livros inspiradores, as fotografias, os desenhos, os presentes que chegaram e tantas outras coisas. Cada caixa contava uma história diferente: histórias do congado, dos mamulengos, dos brinquedos, dos bumba-bois... Cada uma dessas caixas tinha seus próprios objetos, suas pequenas miudezas, que, como "metáforas vivas", segundo expressão de Francisco Régis Ramos (2004), contam do vivido na escola.

Pensar por metáfora significa debruçar-se sobre o real para transcendê-lo, é suplantar a ambição da cópia fiel do acontecido, ultrapassando o chamado significado literal das coisas. (...) o sentido metafórico 
mobiliza um conceito menos dogmático de verdade enquanto correspondência pura entre discurso e ação. (RAMOS, 2004, p. 57)

Por serem metafóricos, esses objetos são abertos a muitos olhares, a muitas significações, que variam de acordo com o olho de quem vê, de acordo com o ponto de vista de quem observa. Olhares que se expandem na medida em que essas caixas não ficaram restritas apenas aos olhares dos meninos, mas acabaram por extrapolar os muros da escola e se estender às suas famílias, pois agora essas caixas tornaram-se viajantes, mensageiras das histórias vividas na escola. A cada dia uma criança levava a caixa para casa, para mostrar e contar o que vivenciaram na escola por meio destes objetos portadores de história, que, de acordo com Passolini, são capazes de comunicar "o invisível que se presentifica na linguagem imagem das coisas".

Foi a partir dessa característica de tornar presente, a partir das imagens, o vivido, que as caixas foram se constituindo também, além da sua função pedagógica, em instrumento de pesquisa, na medida em que permitiam investigar quais reminiscências, quais narrativas surgem nas casas das crianças a partir da chegada dos objetos. O circuito se fez da seguinte forma: as crianças levavam estes objetos para as suas casas e lá eles são recebidos, percebidos e reinterpretados dos mais diferentes modos e são também capazes de provocar as mais diversas situações. Essas crianças, quando voltam com as caixas para a escola, costumam voltar também com suas histórias pra contar, histórias de repúdio, de aconchego, de lembranças propiciadas pelos objetos. Por vezes, voltam também com seus silêncios e atitudes de indiferença por parte das famílias, que, do mesmo modo que as histórias a serem contadas, precisam também ser auscultados e inquiridos quanto aos seus significados. Por um lado, passou-se aos registros em notas de campo das falas destes meninos no grupo, na roda com as outras crianças, com a professora de referência, e nas conversas soltas e entrevistas, acreditando-se na peculiaridade e na autoria do discurso infantil. Além disso, ao se tomar como referência de análise a possibilidade inventiva dos sujeitos na apropriação dos objetos culturais, assumia-se como válida a perspectiva de Michel de Certeau (1995; 1996) quanto às subversões, reinvenções e criações próprias da arte do fazer cotidiano. Mas o olhar das crianças, os seus pontos de vista, são apenas um dos lados da mesma moeda. O segundo passo, depois de ouvi-las, é partir para o encontro com as famílias, buscando, por meio de entrevistas, rastrear processos de significação do mesmo fenômeno, buscando compreender, por exemplo, quais as situações provo- 
cadas pela presença destes objetos, que fios foram constituídos nas conversas, que lembranças foram afloradas. Interessava verificar se a presença das caixas nas casas das famílias adquiria ou não a potencialidade de geração de um momento narrador, na perspectiva benjaminiana de narrativa (BENJAMIN, 1987). Dessa forma, cruzando os olhares e as falas das famílias e das crianças, se teciam tramas capazes de indicar pistas de uma possível revitalização dos elos geracionais a partir do que se vive na escola.

A tentativa era de perceber se essas caixas, no seu papel de mensageiras da experiência, são capazes de costurar elos entre pais e filhos, netos e avós, na medida em que podem se constituir em objetos significativos para as diversas gerações envolvidas, e que, portanto, podem produzir narrativas do vivido. Tanto isso valeria para as crianças que contavam suas histórias a partir da ótica da novidade - por meio do relato e das impressões do tão recentemente vivido na escola - quanto das pessoas mais velhas, que narravam a partir do ponto de vista de suas lembranças. Neste caso, eram narrativas constituídas no presente, porém, com os olhos virados para o passado em que tais festas ou brinquedos ou cantigas eram experienciados, um elo aberto com outro tempo que, por esta razão, converter-se-ia em elemento constitutivo de consciência histórica.

Para nos aprofundarmos mais nos sentidos destes baús guardadores de memórias, cabe aqui uma reflexão sobre os objetos que neles são guardados, que se fazem representantes de histórias vividas, que se abrem à proposta de uma aventura afetiva.

Esses objetos surgem na esteira de uma sociedade marcada pela fluidez e pela massificação que dificultam a continuidade das memórias por sobrecarregar os tempos e os ritmos das pessoas com o consumo de objetos destinados a não se perpetuarem, ou seja, ao consumo de descartáveis (BAUMANN, 2001). Nos tempos atuais, não mais se encontram trabalhos e objetos que antes eram voltados para a continuidade do mundo, objetos que acompanhavam gerações, que contavam da trajetória dos mais velhos. O que hoje predomina são tarefas e objetos que se esgotam na própria vida individual, que não se propõe deixar nenhum vestígio no tempo. Por não deixar marcas de sua passagem pelo mundo, o desaparecimento destes objetos funda buracos e abismos que dificultam a compreensão das nossas "idas e vindas no mapa da temporalidade" (RAMOS, 2004), ou seja, impedem nossa leitura das continuidades da história a partir da materialidade das coisas.

Se vamos apagando a materialidade do pretérito, vamos esvaziando do jogo do tempo, aniquilando o processo educativo de entrar em 
contato com o tanto de experiência vivida que pode ser encontrada no mundo dos objetos. (RAMOS, 2004)

É a partir dessa potencialidade narradora dos objetos, que podem ser compreendidos como vestígios do passado, como receptáculos dos "sinais da humanidade", que os baús foram sendo confeccionados na escola. E aqui cabe uma discussão sobre a natureza desses objetos e suas possibilidades de provocar memórias. Ao contrário dos objetos biográficos, que são "aqueles que envelhecem com o possuidor e se incorporam à sua vida" (RAMOS, 2004), ou seja, são aqueles objetos que, de acordo com Ecléa Bosi (2003), dão assentimento à nossa identidade e falam à nossa alma em sua língua natal, estes objetos criados na escola, ou a partir do trabalho lá realizado, e guardados nas caixas não são testemunhas "oculares" do passado mais remoto, não estiveram lá, não acompanharam a trajetória de vida das pessoas da comunidade. Então como estes objetos podem ser capazes de despertar reminiscências nestas pessoas?

Esses objetos nascem no hoje, mas já com o olhar apontado para um passado, são objetos já nascidos sob o signo da memória. São destinados a narrar lembranças, histórias de hoje (o trabalho com as tradições na escola) mescladas às histórias de outro tempo que pode ou não vir a ser encontrado por novos espectadores a partir do contato com o trabalho escolar. São objetos que, pela própria natureza ou pelo próprio modo como nasceram, a partir do ritmo lento das mãos, da confecção cuidada e única, são capazes de deixar marcas de cada pessoa envolvida na sua construção: os pontos mal-alinhavados das crianças, os desenhos de cada uma delas, os chocalhos amassados pelas brincadeiras, as bonecas de milho e papel e os bichinhos de chuchu feitos pelas mães e avós, tão delicadamente efêmeros e frágeis ao toque mais abrupto, ao tempo mais demorado, mas tão eternamente lembrados. Neste sentido, no modo artesanal de produção e nas tradições que comunicam esses objetos de dentro das caixas podem se constituir tal como os "lugares de memória" apontados por Pierre Nora, em receptáculos de lembranças e significados sociais e subjetivos.

Os lugares de memória nascem e vivem do sentimento de que não há memória espontânea, que é preciso criar arquivos, que é preciso manter aniversários, organizar celebrações, pronunciar elogios fúnebres, notariar atas, porque estas operações não são naturais. E por isso a defesa, pelas minorias, de uma memória refugiada sobre focos privilegiados e enciumadamente guardados nada mais faz do que levar à incandescência 
a verdade de todos os lugares de memória. Sem a vigilância comemorativa, a história depressa os varreria. São bastiões sobre os quais se escora. Mas se o que eles defendem não estivesse ameaçado, não se teria, tampouco, a necessidade de construí-los. Se vivêssemos verdadeiramente as lembranças que eles envolvem, eles seriam inúteis. E se, em compensação, a história não se apoderasse deles para deformá-los, transformá-los, sová-los, petrificá-los, eles não se tornariam lugares de memória. É este vai e vem que os constitui: momentos da história arrancados do movimento da história, mas que lhe são devolvidos. Não mais inteiramente a morte, como as conchas na praia quando o mar se retira da memória viva. (NORA,1993, p. 23)

Objetos dos baús recém-nascidos pelas mãos das crianças, de pais, avós que agora recordam e refazem o vivido, não do mesmo jeito e nos mesmos contextos que eram feitos no passado, mas a partir de uma opção fortemente contemporânea ligada ao cuidado com o mundo, com o ambiente e a arte, bem como ligado ao cuidado com o mundo das tradições. Objetos que nascem a partir de um projeto de escola que cuida de recriar um universo de contato com retalhos e sobras, que, em outros tempos, eram usados nas mais diversas artesanias, como a tradição de fazer bonecas e outros brinquedos, de se contar histórias... Assim, ao criar um local "com outros ritmos, objetos, tempos, cria-se outras possibilidades de gestos, palavras, subjetivações e experiências" (OLIVEIRA JR., 2007). É nesse sentido que as caixas vão se fazendo um "local de memória", por metamorfosearem objetos simples e cotidianos, como brinquedos e desenhos, em objetos especiais, permeados de significados e afetos que os tornam preciosidades capazes de vivificar memórias esquecidas.

Esses pequenos baús portam um duplo sentido, uma dupla razão de existir: podem evocar a imagem de relicários, mas também podem se assemelhar a janelas. Ao serem fechadas, essas caixas são guardiãs de coisinhas esquecidas, algumas já cansadas e outras recém-nascidas. Caixas que ganham a condição de relicários por se fazerem receptáculos dos objetos que, guardados no seu interior, ganham a dimensão de relíquias que devem ser protegidas da devastação dos esquecimentos. Ao serem abertas, no entanto, essas caixas se fazem janelas, alargando a vista para outros mundos, outros tempos. Nesse sentido, um pouco do que se viveu no tempo curto da ação escolar pode ser compartilhado e apropriado, de modo assíncrono, por sujeitos que não estiveram presentes naquele cenário, que aparece, contudo, elucidado por seus próprios atores, no 
caso, as crianças. Os objetos então, antes fechados em caixas (e todos nós sabemos da sedução e da curiosidade despertada diante de um baú fechado...) são agora abertos à contemplação, e por serem objetos porosos, passíveis de serem atravessados pelo olhar e pela imaginação humanas, se prestam a toda sorte de significação.

O objeto não é passageiro, emerge como materialidade de afetação: afeta os passantes humanos, na condição de artefato do tempo. Objeto gerador, gerado na potência de ser atravessado pelo olhar, de ser emotivo e dramático, ou sutil e quase imperceptível, mas sempre indutor ou receptor) de novas configurações de percepção. (RAMOS, 2004, p. 151)

Ao saírem dos baús e serem colocados à disposição do olhar, aquela boneca de pano, aquele botão enferrujado, aquele retrato não são mais os mesmos. Agora, depois de ordenados e cuidadosamente arrumados dentro das caixas, estão transformados em objetos contadores de história. Como parte de uma coleção, foram escolhidos para estarem juntos ali dentro de uma das caixas porque algo maior os unia e os tornava íntimos uns dos outros. E se cada um desses objetos sozinho é capaz de contar uma história, quando agrupados a outros objetos tecem uma trama, uma colcha de retalhos que mescla vidas, lembranças, imaginações e recordações que fazem com que uma pessoa reconheça sua história no fragmento de vida de outra pessoa e, portanto, fazem da narrativa de um parte da história de todos.

(...) Quem somos nós, quem é que cada um de nós é senão uma combinatória de experiências, de informações, de leituras, de imaginações? Cada vida é uma enciclopédia, uma biblioteca, um inventário de objetos, uma amostragem de estilos, onde tudo pode ser constantemente remexido e reordenado de todas as maneiras possíveis. (CALVINO, 1990, p. 35)

Cada vida é, portanto, um baú, como aqueles de fundo falso, aberto às profundezas. É uma coleção de badulaques, um acervo de relíquias, todas possíveis de serem transformadas em histórias contadas. É neste sentido que estes báus e seus guardados surgem como sinaleiros capazes de iluminar os possíveis rastros (nesta sociedade que, cada vez mais, se nega a deixar rastros) de lembranças e histórias vividas e que se prestam ao desafio de fertilizar as imbricações entre passado, presente e futuro. 


\section{TRANSFORMANDO RELICÁRIOS EM JANELAS:}

\section{caixas e objetos escolares ressignificados na relação entre escola e família}

Para a viabilização da proposta de investigação, foram escolhidas apenas duas dessas caixas, em um universo maior disponível na ação escolar: a Caixa do Congado e a Caixa dos Brinquedos. Esta escolha não foi feita aleatoriamente, mas considerou as distintas possibilidades de engendramento de experiência que cada uma delas propunha. Por um lado, a caixa dos brinquedos era capaz de soar familiar e encontrar ressonância quanto ao significado para a maioria das pessoas - que, em uma época da vida, já foram crianças e, portanto, sujeitos brincantes. Por outro lado, a caixa do congado já não contava com a mesma sorte, com a mesma universalidade, uma vez que materializava uma tradição que envolvia práticas de devoção comunitárias bastante particulares, que podiam encontrar ou não significado junto àquelas famílias. Tendo em vista a perspectiva de potencial estranhamento frente à experiência do Congado pela maior parte das pessoas que habitam sobretudo as áreas urbanas, nossa opção neste artigo, focado numa temática relativa ao ensino de História, recairá sobre a descrição apenas daquela primeira caixa, ficando para o leitor o convite à leitura do trabalho em sua íntegra.

O intuito da investigação era desvendar a potencialidade de evocar lembranças vividas e, se possível, narradas a partir da chegada destas caixas nas casas das crianças. O circuito se fazia assim: as crianças vivenciavam um trabalho na escola (roda do congado, oficina de brinquedos), depois, ou durante o processo, alguns objetos pertencentes a essas vivências eram guardados nas caixas, que, por sua vez, eram levadas para as casas das famílias. Quando retornavam com as caixas, as crianças contavam, na roda, sobre como havia sido a visita e, depois, para completar e cruzar os dados com o discurso de meninos e meninas, era feita uma entrevista com a família. Dessa forma, se buscava rastrear os significados desses objetos em relação às histórias de vida das famílias das crianças, atentando-se, principalmente, para suas potencialidades de iluminar reminiscências e gerar elos narrativos entre as crianças e os mais velhos. A partir do itinerário dessas caixas, foi possível rastrear partes dos sistemas de significados culturais dos sujeitos estudados a partir da sua ótica do mundo e do seu universo referencial. Neste rastrear de pistas destes sistemas simbólicos, que podem passar despercebidos ao olhar mais desatento, confundido com ruídos sem importância, o trabalho de pesquisa se assemelhou ao do caçador que, na busca de sua presa, não se deixa confundir pelas inúmeras ciladas do caminho. Isso corresponde ao que 
Ginzburg (1987) caracterizou como a capacidade de, a partir de dados aparentemente negligenciáveis, remontar uma realidade complexa nãoexperienciável diretamente.

Faz-se importante dizer que a escolha dos sujeitos de pesquisa não foi tarefa fácil. Muitas crianças levaram as caixas e continuam levando, mas, como foi possível verificar, os procedimentos metodológicos exigiam muita dedicação, análise cuidadosa e sensibilidade, o que impedia que um número grande de casas fosse analisado. Assim os sujeitos foram escolhidos a partir do desejo de levar as caixas logo de início e pelo interesse e envolvimento durante os processos desenvolvidos na escola.

Deixar que as crianças levassem esses objetos para a casa requer um voto de confiança, afinal tudo poderia acontecer: os objetos poderiam se perder, alguma coisa poderia se rasgar, estragar. Poderia ser também que, por excesso de zelo das famílias, as caixas fossem guardadas no alto de estantes e armários e lá ficassem esquecidas até o dia de retornarem para a escola. $E$ foi pensando em tudo isso que a primeira caixa do Congado foi entregue ao Vinícius no final de um dia de aula, cena que se repetiria por várias vezes ao longo de meses e instituiria uma rotina escolar disputada pelas crianças.

Dentro da caixa, restavam os rastros do que havia pautado, ao longo dos meses anteriores, a abordagem desse folguedo na escola, reinventado pela brincadeira de roda pontuada pelas cantigas e batido de tambores típicas dos cortejos dos reis de Congo. Ao ser transposta para o universo da escola pública, que se propõe laica, o congado teve de ser destituído dos seus aspectos religiosos e ser ressignificado na prática pedagógica. Desta reinvenção de tradições, tanto da cultura da escola quanto das tradições populares, surge a possibilidade de rompimento do silêncio da escola diante dessas manifestações populares dentro de seus currículos, o que possibilita que pelo menos se vislumbre de alguma forma os significados inerentes a essas manifestações. Significados, que no caso do congado, podem ser pressentidos a partir das narrativas, das indumentárias, dos baques dos tambores que assinalam para uma forma de resistência alegre e festeira dos negros em resguardar suas origens (PEREIRA, 2005).

Mesmo transformada, esta roda de crianças e seus tambores reatualiza, no presente, uma prática ancestral que perpetua a memória do vivido em outros tempos e espaços. Quando o congado é deslocado do seu ambiente original e levado para o contexto escolar, ele se transforma na medida em que alguns elementos permanecem - as músicas, as danças, as narrativas... - enquanto outros passam a ser abordados com menos 
destaque, como os aspectos devocionais e religiosos (PEREIRA, 2002). A proposta é que a presença desses elementos que permanecem seja capaz de garantir que um pouco da trajetória desses velhos congadeiros seja contada aos meninos de hoje, em um lugar no qual essa tradição já não vive e que, por meio destes meninos, seja perpetuada nas suas rodas, brincadeiras e possam buscar possíveis elos com a trajetória de vida das próprias crianças por meio das reminiscências familiares que possam surgir a partir deste trabalho realizado na escola.

O trabalho com a Roda dos Reizinhos de Congo esteve presente na escola durante todo o semestre e, no fim daquele ano, como registro do que fora vivido, foi montada a caixa de guardados do congado. Nesta caixa, armazenaram-se alguns objetos que se foram constituindo como registros portadores de uma memória afetiva das experiências vividas durante o tempo em que as crianças brincaram a roda.

Os primeiros objetos que surgiram foram os bonecos do reizinho e da rainhazinha conga. Esses bonecos foram costurados junto com as crianças no espaço/tempo da brincadeira. Eram bonecos feitos de feltro e malha preta e recheados com lã de carneiro. Durante o processo de confecção, que durou muitos dias, as crianças iam ajudando a limpar a lã do recheio, trançar os cabelos, escolher os bordados das capas reais e dar um ou outro ponto na costura. No dia em que os bonecos ficaram prontos, foram recebidos na roda de histórias em volta da vela com muitos "vivas" e muita alegria. Os reizinhos, então, passaram de mão em mão e receberam muitos beijos e abraços, até serem colocados no centro da mesa. Esses bonecos trazem as marcas do trabalho das crianças nos seus pontos tortinhos, nos penteados de seus cabelos e nas cores de suas capas, e materializam em miniatura a história e os personagens vividos na roda. Desde que ficaram prontos, os bonecos foram colocados na mesa da época e lá ficaram até o fim do ano, como uma marca do tempo e do trabalho em curso.

Contagiada pela empolgação das crianças, outra professora resolveu fazer também uma oficina de chocalhos, que eram confeccionados com latinhas de cerveja e refrigerantes, encapadas com chita e cheias de grãos de arroz. Com esses instrumentos, as crianças iam exercitando o seu senso rítmico nas brincadeiras à moda dos patangome (instrumentos de percussão típicos do congado, feitos com lágrimas de nossa senhora). Além das cantorias, as crianças também quiseram fazer muitos desenhos: figuras da rainha, com seu manto azul de flores e estrelas, o Rei do congo, com sua capa vermelha, rodas de tambores, castelos... A vida da roda não 
se cansava de ser representada naqueles desenhos. Foram tantos desenhos que se decidiu organizá-los no que as crianças chamaram de "livro de desenho". Mas, na medida em que os desenhos eram organizados no livro, emergia a necessidade de completar o arranjo com as narrativas do que era feito. E então vieram as letras das músicas, os versos, as histórias... E depois chegaram as fotografias da roda, do congado de Santana dos Montes, da aluna dançando numa casa de espetáculos da cidade e tantas outras. Então o que era só um livro de desenhos se tornou o "Livro Rosa" ( porque tinha como suporte folhas de papel ofício cor-de-rosa), que é como as crianças chamam este livro de registros que narra e reconta a história desta experiência. É um livro que as crianças não se cansam de olhar e de contar umas para as outras, falando das muitas lembranças que surgem quando olham para aqueles registros: "Olha só, o Heleno. Pena que ele não estuda mais aqui", "A Rafaela ta dançando no Mescla neste retrato, mas eu é que fui a primeira rainha conga!", "lembra aquele dia que a gente foi de ônibus praquela escola dançar e caiu uma chuvona que todo mundo teve de ficar encolhidinho?"...

Outro objeto muito precioso que também chegou no tempo das congadas foi o chaveiro que o pai do Heleno fez com a foto dele vestido de rei. No dia em que o Heleno trouxe o chaveiro a primeira vez para a escola, ele chegou exibindo aquele chaveiro para as outras crianças, que olhavam para aquele objeto com muita admiração, como se olhassem para uma medalha. O pai do Heleno, a pedido da diretora da escola, mandou de presente outro chaveiro, igualzinho ao primeiro, para guardarmos de recordação na nossa caixa. O chaveiro ganhou um significado ainda mais especial quando o Heleno se mudou e teve de sair da escola, tornando-se uma lembrança do amigo que se foi.

A partir desses objetos, foi-se constituindo a caixa de memórias do congado da escola. Além deles, também foi colocado lá dentro o livro dos Reizinhos do Congo do Edmilson Pereira, por ter sido a partir dele que a idéia da roda surgiu.

Como podemos ver, cada um desses objetos da caixa - o livro rosa, o livro do Edmilson. o chaveiro, os chocalhos e os bonecos de pano - conta um fragmento do que se viveu, ou seja, tem papel fundamental na narrativa da experiência. E como já foi dito quando discutimos o significado dessas caixas, logo a caixinha do congado se tornou viajante, indo visitar a casa das crianças na tentativa de descobrir qual a potencialidade destes objetos (e, conseqüentemente, do próprio trabalho da escola) de evocar reminiscências e histórias a serem contadas. 
Ao levar a caixa pra casa, no início da jornada das viagens, logo Vinícius surpreendeu dizendo assim: "Ô tia Gisa, você não tem uma sacolinha de Bahamas [sacola de supermercado] pra eu levar a caixa, assim ela não suja". Como na escola não foi encontrada nenhuma sacola, ele resolveu embrulhar a caixa no casaco e, assim, saiu todo satisfeito com aquele embrulho improvisado. $\mathrm{O}$ zelo demonstrado por ele era surpreendente, visto que nenhuma recomendação de cuidado havia sido feita. Era como se o Vinícius reconhecesse, naqueles objetos, preciosidades. Afinal, ele havia participado da confecção dos bonecos, dos chocalhos e do livro rosa. Havia presenciado a coroação dos reis na roda, ajudado a caixa a ser montada e na rememoração do vivido cada vez que ela era aberta na nossa sala. Para ele, cada objeto daqueles continha também um pouco da sua própria trajetória na escola. E, talvez, por tudo isso, ele tenha, naquele dia, enrolado a caixa no casaco querendo protegê-la.

Seguindo o roteiro do circuito das caixas, nos dias seguintes à sua viagem, seria o momento de ouvir sobre como havia sido a visita. Foi na roda que se desenvolveu a conversa sobre como havia sido a visita da caixa na sua casa. Ele logo pegou a caixa e foi contando

Vinícius: Eu botei a caixa em cima da mesa lá da cozinha, peguei os bonecos assim, ó, e coloquei essa florzinha aqui, aqui no meio [enquanto falava, ia montando o cenário em cima de um paninho de renda que ficava dentro da caixa]. E aí chegou o reizinho do congo: Vosso rei pede uma dança é de ponta de pée é ce calcanhar... [a partir daí começou a cantar a música do rei e, depois, com a participação das outras crianças da roda, foi encenando, ali, com aqueles objetos, a história do rei e da rainha que a gente fazia na grande roda dos reizinhos]

Gisa: Você contou tudo isso lá na sua casa?

Vinícius: Tudinho.

Gisa: E a tua mãe, a dona Célia, ela gostou?

Vinícius: Hum, hum. Ela disse que o congado... que ela já tinha visto. Mas que era de um outro jeito. Não tinha o rei. Não tinha nem a rainha conga, tia Gisa! Gisa: Então o que é que tinha?

Vinícius: Tinha os tambor... tinha uns homem e tinha uns meninos do meu tamanho que batia uns pedaços de pau assim: clac, clac, clac

Gisa: Só isso?

Vinícius: ... é [pausa, fica pensando]. Só isso mesmo.

Observa-se, pela fala do Vinícius, que a caixa tinha sido capaz de elucidar uma experiência, foi capaz de puxar um fio com outro congado, de um outro tempo e de outro lugar. E a partir dessa lembrança, surgiu também a vontade de contar da própria experiência no presente, o que fica evidente quando o Vinícius nos conta daquele congado que "nem rainha conga tinha!", um congado de homens e meninos batendo paus. 
A entrevista com a mãe, a dona Célia, só pôde acontecer na semana seguinte por causa dos horários de trabalho dela e da Emília, a mãe da Jéssica, que também havia levado a caixa para casa. A primeira a falar foi a Emília, que é mesmo mais falante, mais extrovertida.

Emília: Na hora que eu vi os retratos do livrinho eu logo falei pras meninas: “ih, olha só, agora aqui também ta tendo congado! Porque você sabe, né? Ô lugar pra não ter nada. Não tem uma festa, não tem nada. Quando eu morava lá no João Gomes, que é onde eu nasci, tinha um tanto de coisa. Tinha congado, procissão de nossa senhora da Aparecida, festa de Santo Antônio com barraquinha, fogueira... Eu e a Célia ia em tudo junto, né, Célia?

Célia: Ih, se era! Era bom demais! Quando o Vinícius trouxe a caixa, eu lembrei lá das festas do Zé Olinto. Só que lá era muito diferente. O congado dele era bonito que só! Os homem ia tudo de branquinho, batendo os paus e dançando. Mulher não podia participar. A gente ia logo atrás do congado, mas ia junto com as menina que ia coroar. Ia o congado na frente, puxando a procissão, e a coroação atrás. Aí, quando chegava perto da igreja, eles paravam e cruzavam os paus, fazendo tipo um túnel pras meninas da coroação passar. Nisso, os tambores iam tocando. Aí elas passavam e começava a coroação.

Nestes trechos da conversa, já algumas das pistas se apontam. Tal como o relato do Vinícius na roda anunciara, os objetos da caixa, mesmo causando algum estranhamento pela presença de alguns elementos alheios ao universo simbólico já conhecido da congada (presença do rei e da rainha), foram capazes de gerar uma relação de pertencimento a partir de outros elementos significativos (as cantigas, os tambores, as fitas...). E, deste reencontro com um pedaço ainda que pequeno da própria vida, vem também a vontade de contar a história do vivido, mesmo que uma história feita de pequenos fragmentos de lembranças. Lembranças que levam a uma comparação entre os ritmos e relações comunitárias estabelecidas no lugar de origem e o espaço de vivência atual, marcado pela desterritorialização e a ausência de relações simbólicas com a perspectiva de Lugar, segundo aquilo que nos é apontado pelas análises de Y Fu Tuan (1983). Se, no primeiro, havia um calendário fixo de festas religiosas que cuidavam de agregar a comunidade em um movimento feito a partir do coletivo, o segundo é marcado pela ausência desses encontros, dessas festas que têm papel fundamental na constituição do sentimento de pertencimento do sujeito em um grupo. Essa comparação fica clara quando a Emília, ao se lembrar das congadas do bairro João Gomes Velho, onde morava, se refere ao local onde mora hoje como "um lugar que não tem nada! Não tem uma festa pra gente ir, não tem nada!”. E a conversa continua e, na cozinha da casa da Emília, muitas outras 
histórias se afloram. Dona Célia e a Emília, além de cunhadas, eram amigas desde pequenas, pois eram vizinhas. Em seus diálogos, contos relativos ao começo da vida, das brincadeiras, de quando a Emília teve de fugir com o irmão da Célia pra poder casar, das aventuras de chegarem juntas em Juiz de Fora e começar uma vida nova. Ainda no rastro das lembranças despertadas pela caixa do congado, outra história se aponta:

Emília: O meu sonho era coroar Nossa Senhora. Demorou muito, mas um dia eu fui escolhida. Eu já tava toda nervosa, então, quando eu cheguei lá em cima do altar, pronta para coroar, de repente eu reparei na Célia lá em baixo rindo de se acabar. Aí me deu foi vontade de rir, bem na hora de coroar. Eu não consegui segurar. Aí veio a Olinda, que era quem ensaiava a gente, e me deu um pito na frente de todo mundo. Como é que pode, na hora de coroar ter vontade de rir daquele jeito. [risos]

Vinícius: E você tava rindo de quê naquela hora, mãe?

Célia: Ah, sei lá meu filho, bobeira de criança. [risos]

Ali, durante a entrevista, as memórias daquelas duas mulheres foram se cruzando, se completando, uma puxando uma meada que se encostava ao pedaço de vida da outra. Assim, as lembranças foram chegando e foram narradas no meio dos risos, das saudades e do olhar curioso e atento das crianças ao verem ali as mães naquela cumplicidade das meninas que foram um dia. Com isso, o momento da entrevista pôde se constituir, ele próprio, em um ambiente narrador.

Em outro cenário, um elo de significação notadamente distinto: a situação em que a narrativa provocada pela caixa não engendraria nenhuma reminiscência, nenhuma transmissão de experiência, nem tampouco uma narrativa. Foi o que se passou com o Heleno, primeira criança a levar a caixa para casa justamente por ter sido, nas rotinas e representações elaboradas na escola, o primeiro Rei Congo. Luiza, sua irmã mais velha, quis levar a caixa pra ele, mas ele fez questão de carregá-la sozinho, dizendo: "Essas são minhas coisas de rei". Com o Heleno, não foi possível ouvir suas impressões da visita da caixa à sua casa, pois ele ficou doente e faltou às aulas por mais de uma semana. Foi a irmã que devolveu a caixinha no dia seguinte. $\mathrm{Na}$ visita que instauraria a entrevista com a família, as primeiras impressões da mãe Luciene sobre os efeitos gerados em casa pelo trabalho escolar, uma outra configuração na visita da caixa:

Luciene: Ele chegou eu não tava em casa. Aí eu cheguei e a caixa tava ali. Aí eu perguntei: “Que caixa é essa?”, eu achei que era um sapato, né? Aí ele: "Não mãe, a tia Gisa que mandou pra você ver, depois vai pra casa das outras crianças. Aí eu fui abrindo, aí ele pegou o chocalhinho, tocou, cantou, mostrou o rei e a rainha, aí os livrinho. Eu achei a coisa mais linda! E o mais importante foi que eles que desenharam, né? Teve também as fotos, ficou muito bonito, um ótimo trabalho! 
Pelo tom da resposta, o pressentimento de que talvez os objetos da caixa não tivessem elucidado nenhuma experiência vivida, o que viria reforçado em sua fala seguinte:

Luciene: Ah, não lembrei de nada não. Porque quando a gente estuda é pra gente passar, né? Depois que a gente sai da escola é que a gente vê: "Ai, por que que eu não aproveitei?” Então se esse negócio de congado... é folclore, né? Se esse negócio de congado teve na escola, passou batido por mim.

Para a Luciene, o congado surge como uma experiência completamente alheia à sua história de vida. $\mathrm{Na}$ tentativa de buscar alguma significação para aqueles objetos, para aquele folguedo, foi buscar alguma informação nos seus registros de escola, onde não encontrou nada, além de uma vaga lembrança: "É folclore, né?" Os objetos da caixa não lhe provocaram qualquer sentimento de pertencimento e, por isso mesmo, não foram capazes de gerar qualquer narrativa. O olhar que a Luciene teve ao abrir a caixa foi o de quem avalia um trabalho desenvolvido na escola: O capricho na organização do material, a criatividade das crianças expressa nos desenhos, o orgulho de ver o filho em papel de destaque na escola. E apenas isso. Por não encontrar ressonância com nenhuma experiência vivida na sua história de vida, o encontro com a caixinha do congado não lhe aflorou nenhuma lembrança, nenhuma reminiscência, nenhuma aventura afetiva (BOSI, 2003). Naquela casa, nenhuma janela foi aberta a partir do encontro com a caixa.

Durante cada uma dessas viagens, os objetos que a ela pertencem propuseram um jogo à imaginação e à memória. O que pudemos ver aqui então foi alguns dos roteiros propostos, alguns dos trajetos traçados por essas janelas abertas (quando elas foram abertas), numa paisagem que variou de acordo com o olho de quem via, de acordo com as histórias de vida com as quais esses objetos se cruzaram.

\section{CONSIDERACְ̃̃ES FINAIS}

Acreditamos que se, por um lado, falamos aqui de Ensino de História e da potencialidade do uso pedagógico de objetos na escola, por outro lado, conseguimos evocar muitas outras coisas, bem mais profundas e diretamente relacionadas à educação da sensibilidade histórica dos sujeitos, na perspectiva destacada por Marc Bloch (1997). A pesquisa sobre a qual se ancorou nossas análises neste artigo, além de elucidar formas particulares de se produzir uma ação promotora da consciência histórica na ação escolar, discute elos entre infância, experiência, escola e Memória, na contemporaneidade. Trata-se de um conjunto de elos essen- 
ciais ao enfrentamento de um amplo universo de questões e temáticas no âmbito da pesquisa educacional.

Sob o ponto de vista da criança, este tipo de experiência pode ser fundamental para a ampliação das possibilidades de produção de sentidos, das estratégias de leitura de mundo.

$\mathrm{O}$ desejo de falar vem à criança pela música das vozes que a envolve, nomeia e chama a existir por sua conta. Toda uma arqueologia de vozes codifica e torna possível a interpretação das relações, a partir do reconhecimento das vozes familiares, tão próximas. Músicas de sons e de sentidos, polifonia de locutores que se buscam, se ouvem, se interrompem, se intercruzam e se respondem. Mais tarde a tradição oral que recebeu servirá à criança para medir a sua capacidade de ler. Só a memória cultural que se assim se adquire permite enriquecer, pouco a pouco as estratégias de interrogação dos sentidos. A criança aprenderá a ler na expectativa e na antecipação do sentido, uma e outra nutridas e codificadas pela informação oral da qual já disporá. (CERTEAU et al., 1996, p. 336)

Cada uma das caixas estabelecia formas distintas de relação com os sujeitos. Enquanto os objetos pertencentes ao congado reinventado na escola cavavam seus sentidos junto às famílias a partir de uma vivência contruida no interior da própria escola e que, na comunidade estudada, apenas testemunhavam vagas lembranças de algo vivido furtivamente em outros tempos (isso quando não causavam estranhamento), a caixa de brinquedos, pelo seu caráter mais universal, era capaz de fazer surgir sempre alguma recordação do brincante de ontem dentro do adulto de hoje.

A partir do processo da pesquisa que envolveu a confecção e a viagem das caixas, o encontro com as famílias e a fala das crianças, foi se apontando algo que, de certa forma, contrariava o que era preconizado pelos teóricos que contavam do fim das experiências narradas: o que se encontrou, em algumas famílias, foi um ambiente narrador, lugar onde as histórias contadas e relembradas ainda podiam estar presentes. Nessas casas, onde os objetos portadores de memórias (álbuns de retratos, coisas que pertenceram aos antepassados...) eram quase inexistentes, as narrativas ainda encontravam seu lugar como elo que norteia o sujeito dentro da sua própria história. O que acontecia, muitas vezes, é que esse potencial narrativo se encontrava adormecido devido aos ritmos acelerados da modernidade, que, no caso destas famílias, se faz perceber, principalmente, pela ausência de vestígios materiais capazes de evocar lembranças e pela jornada intensa de trabalho dessas pessoas, o que impede os encontros coletivos demorados e mais freqüentes. Durante o trabalho da 
pesquisa, o que se fez foi "cutucar com vara curta quem estava quieto", ou seja, por meio dos elementos das tradições vividas na escola e materializadas nas caixas, o que se buscou foi fazer com que estas histórias viessem à tona com todo vigor, com todo um jeito cheio de vida de evocar as reminiscências. Uma empreitada às vezes bem-sucedida e às vezes não, pois tudo dependia dos significados estabelecidos entre os objetos das caixas e a história de vida de cada família.

Ao final da pesquisa, o que se evidenciou foi a possibilidade de essas tradições populares se constituírem como um universo amplo e riquíssimo a ser explorado na escola, como um caminho capaz de estabelecer elos bastante significativos não só entre as crianças e seus familiares, mas entre as famílias e a instituição escolar. Ao longo deste estudo, o que se pôde perceber foi que quando a escola se propõe trabalhar com a cultura popular como parte de um sistema de significação vivo e, por isso mesmo, flexível e aberto a possíveis transformações, ela se lança na aventura de inventar e arriscar formas de jogar com as diferentes manifestações culturais. Se com os brinquedos artesanais o jogo se fez de forma mais fluida e encontrou ressonância nas crianças e nas suas casas, devido à universalidade do universo brincante; o trabalho com o congado já se fez mais intrincado, uma vez que este folguedo, muitas vezes, não fazia parte do imaginário das pessoas ou, se fazia, era de outra forma (um congado sem reis e sem rainhas), a partir de outros contextos.

$\mathrm{O}$ que se contou neste estudo foi a experiência com essas duas tradições, acontecidas em determinado tempo e em determinadas circunstâncias. O que significa dizer que o modo como esses trabalhos foram realizados não está cristalizado, fechado em um único jeito de acontecer. Se o Congado (assim como o auto do Bumba-boi e a festa da Luz) acontece todos os anos na escola e já faz parte da sua tradição, é importante dizer que, a cada ano, um novo jeito de fazer é inventado a partir de novas pesquisas e da própria intervenção das famílias e das crianças. Assim, por exemplo, se o trabalho com o congado iniciou-se como algo pequeno, na roda das crianças da educação infantil, no ano seguinte ele se fez grande, num cortejo de coroação do rei e da rainha conga que envolveu o desfile da mãe África-Brasil e uma mesa de quitutes farta, feita pela própria comunidade. Deste modo, vão sendo inventados na escola outros jeitos de brincar esta festa e, também, as outras, num fluxo que guarda as marcas e as permanências das tradições, mas que também deixa brechas para o novo. Porque se faz dessas tradições algo vivo e pulsante, capaz de descobrir e criar laços e significados entre a vida da escola e a vida das crianças e de suas famílias. Janelas plenas de relicários... 


\section{REFERÊNCIAS}

AGAMBEN, G. Infância e história: destruição da experiência e origem da história. Belo Horizonte: Editora UFMG, 2005.

BAUMAN, Zygmunt. Modernidade líquida. Rio de Janeiro: Jorge Zahar, 2001.

BENJAMIN, Walter. O narrador. In: BENJAMIN, Walter. Obras escolbidas. São Paulo: Brasiliense, 1987.

BLOCH, Marc. Introdução à História. Ed. revista e ampliada por Etienne Bloch. Lisboa: Europa-América, 1997.

BOSI, Ecléa. O tempo vivo da memória: ensaios de psicologia social. São Paulo: Ateliê Editorial, 2003. BRESCIANI, Stela; NAXARA, Márcia (Orgs.) Memória e (res)sentimento. Campinas: Unicamp, 2001. CALVINO, Ítalo. Fábulas Italianas. São Paulo: Companhia das Letras, 2002.

CERTEAU, Michel de. A invenção do cotidiano. 2 ed. Petrópolis: Vozes, 1996.

CERTEAU, Michel de. A cultura no plural. Campinas: Papirus, 1995.

DIEHL, Astor. Cultura historiográfica, memória, identidade e representação. Bauru: Edusc, 2002.

GINZBURG, Carlo. Mitos, emblemas e sinais. São Paulo: Companhia das Letras, 1989.

GINZBURG, Carlo. O queijo e os vermes. São Paulo: Companhia das Letras, 1987.

LE GOFF, Jacques. História e memória. 3 ed. Campinas: Unicamp, 1994.

LUCINI, Marizete; OLIVEIRA, Sandra; MIRANDA, Sonia. Na esteira da razão histórica: diálogos e olhares sobre a obra de Jorn Rusen. In: ZAMBONI, Ernesta. Digressões sobre o ensino de História. Itajaí: Maria do Cais, 2007.

NORA, Pierre. Entre memória e história: a problemática dos lugares. Projeto História, São Paulo, n. 10. p. 7-28, 1993.

OLIVEIRA JR., Wenceslao Machado. Texto apresentado para exame de qualificação de Gisela Marques Pelizzoni, Universidade Federal de Juiz de Fora, janeiro, 2007.

PELLIZZONI, Gisela Marques. Jogando as cinco pedrinhas: História, memória, cultura popular, infância_e escola. (2007). Dissertação de Mestrado. UFJF, 2007.

PEREIRA, Edmilson de Almeida. Flor do não esquecimento: Cultura popular e processos de transformação. Belo Horizonte: Autêntica, 2002.

PEREIRA, Edmilson de Almeida. Os reizinhos de Congo. São Paulo: Paulinas, 2005.

RICCEUR, Paul. A memória, a bistória e o esquecimento. Campinas, SP: Unicamp, 2007.

RÜSEN, Jörn. Razão Histórica - Teoria da História, fundamentos da ciência histórica. Brasília: UnB, 2001.

THOMPSON, E. P. Miséria da teoria. Rio de Janeiro: Zahar, 1981.

TUAN, Y Fu. Espaço e lugar. a perspectiva da experiência. São Paulo: Difel, 1983.

Recebido: $15 / 03 / 08$

Aprovado: 11/04/08

Contato:

Universidade Federal de Juiz de Fora - Faculdade de Educação

Bairro Martelos

Juiz de Fora - MG

BRASIL

CEP: 36036-900

E-mail: sonia.miranda@ufjf.ed.br 